\title{
STUDY ON THE MAGNETIZATION-REVERSAL BEHAVIOR OF ANNEALED Sm-Fe-Co-Si-Cu RIBBONS
}

\author{
ŠTUDIJ VEDENJA PRI OBRATU MAGNETIZACIJE ŽARJENIH \\ TRAKOV Sm-Fe-Co-Si-Cu
}

\author{
Marcin Dośpial, Sebastian Garus, Marcin Nabialek \\ Institute of Physics, Czestochowa University of Technology, Armii Krajowej Av. 19, 42-200 Czestochowa, Poland \\ mdospial@wp.pl \\ Prejem rokopisa - received: 2014-09-04; sprejem za objavo - accepted for publication: 2014-12-09
}

doi:10.17222/mit.2014.219

\begin{abstract}
The paper presents the studies of $\mathrm{Sm}-\mathrm{Fe}-\mathrm{Co}-\mathrm{Si}-\mathrm{Cu}$ ribbons obtained with the melt-spinning technique, annealed at $1123 \mathrm{~K}$ for $3 \mathrm{~h}$. The phase-composition studies were made using a D8 Advance Bruker X-ray diffractometer. It was found that the studied alloy has a multi-phase composition. These studies were of crucial importance in the interpretation of the magnetization reversal. Magnetic measurements, i.e., the major hysteresis loop and recoil curves were performed using a LakeShore vibrating-sample magnetometer with the maximum magnetic field of up to $2 \mathrm{~T}$. On the basis of the recoil curves, the hysteresis loop was decomposed into the reversible and irreversible magnetization components. The decomposed curve was used to describe the processes that influence the reversal magnetization in the studied permanent magnets. Further, these components were used to model the recoil curves, using a modified hyperbolic $T(x)$ model based on the method described by Dośpial. The modeled hysteresis loop and recoil curves revealed a high compliance with the experimental data, proving the validity of the assumptions made in the modeling procedure.

Keywords: permanent magnets, $\mathrm{TbCu}_{7}$ structure, magnetization reversal, hysteresis model

Članek predstavlja študij trakov Sm-Fe-Co-Si-Cu, dobljenih s tehniko "melt-spining", 3 h žarjenih pri 1123 K. Študij sestave faz je bil izvršen z rentgenskim difraktometrom D8 Advance Bruker. Ugotovljeno je bilo, da je preučevana zlitina sestavljena iz več faz. Te študije so bile ključnega pomena pri razlagi obrata magnetizacije. Magnetne meritve, to so glavna histerezna zanka in povratne krivulje, so bile izvršene $\mathrm{z}$ magnetometrom LakeShore $\mathrm{z}$ vibrirajočim vzorcem $\mathrm{z}$ uporabo največjih magnetnih polj do 2 T. Na podlagi povratnih krivulj je bila histerezna zanka razdeljena v komponente reverzibilne in ireverzibilne magnetizacije. Razstavljene krivulje so bile uporabljene za opis procesov, ki vplivajo na obrat magnetizacije pri preučevanih permanentnih magnetih. Nadalje so bile te komponente uporabljene za modeliranje povratnih krivulj z modificiranim hiperboličnim modelom $T(x)$ na podlagi metode, ki jo je opisal Dośpial. Modelirane histerezne zanke in povratne krivulje so odkrile veliko ujemanje z eksperimentalnimi podatki, kar potrjuje veljavnost približkov, uporabljenih pri razvoju modela.

Ključne besede: permanentni magneti, strukture $\mathrm{TbCu}_{7}$, obrat magnetizacije, histerezni model
\end{abstract}

\section{INTRODUCTION}

Alloys with the chemical composition close to $\mathrm{SmCo}_{7-8.5}$ are used for fabricating the materials with a $\mathrm{TbCu}_{7}$ meta-stable structure that cannot exist steadily. ${ }^{1-3}$ Doping elements, such as $\mathrm{Si}, \mathrm{Zr}, \mathrm{Cu}$, etc., promote the crystallization of this type of disordered structure, whose main feature is a positive $\beta$ intrinsic-coercivity temperature coefficient. ${ }^{4,5}$ The annealing process applied to these materials leads to the decomposition of the $\mathrm{SmCo}_{7}$ phase into more stable structures, composed of the $\mathrm{SmCo}_{5}$ and $\mathrm{Sm}_{2} \mathrm{Co}_{17}$ phases. ${ }^{6-8}$

One of the most popular methods for determining the reversal-magnetization process is an analysis of recoil loops. Reversal magnetization in multiphase, nanocomposite permanent magnets, such as annealed $\mathrm{Sm}_{12.5} \mathrm{Fe}_{8} \mathrm{Co}_{66.5} \mathrm{Si}_{2} \mathrm{Cu}_{11}$ ribbons, is very complex and often described with more than one type of process. ${ }^{2}$ On the basis of recoil curves, it is not only possible to determine the number of reversible and irreversible magnetization processes occurring in these materials, but also describing their parameters. ${ }^{6}$
Such information applied to hysteresis models can be used for simulating the major and minor hysteresis loops, the initial magnetization or recoil curves.

The aim of this paper is to present the theoretical description of the major hysteresis loop and recoil curves obtained using a hyperbolic $T(x)$ model modified by Dośpial and its comparison with the experimental data.

\section{MATERIALS AND EXPERIMENTAL PROCEDURE}

Samples of the $\mathrm{Sm}_{12.5} \mathrm{Fe}_{8} \mathrm{Co}_{66.5} \mathrm{Si}_{2} \mathrm{Cu}_{11}$ alloy were obtained from high-purity elements, by arc melting, in a protective argon atmosphere. The studied ribbons were prepared by rapidly quenching the liquid alloy on a rotating copper wheel with a high linear velocity of $20 \mathrm{~m} / \mathrm{s}$. Both ingots and the samples were prepared in a protective gas atmosphere under a pressure of $0.4 \times$ $10^{5} \mathrm{~Pa}$. The obtained ribbons were encapsulated in the argon atmosphere, annealed at $1123 \mathrm{~K}$ for $3 \mathrm{~h}$ and slowly cooled to room temperature. 
XRD patterns were measured using a Bruker X-ray diffractometer equipped with a Lynx Eye semiconductor counter. Diffraction patterns were made using a $\mathrm{Cu}-\mathrm{K} \alpha$ radiation source with a characteristic wave length of $0.1541 \mathrm{~nm}$ in the Bragg-Brentano geometry. The samples for the X-ray measurements were scanned in a $2 \theta$ range from $30^{\circ}$ to $120^{\circ}$ with an angle step of $0.02^{\circ}$ and an exposition time of $3 \mathrm{~s}$. A quantitative and qualitative analysis of the phase composition was carried out using the Brass evaluation program applying the Rietveld profile-matching method. ${ }^{9}$

The major hysteresis loop and recoil curve were measured using a LakeShore VSM with the maximum external magnetic field of $2 \mathrm{~T}$. The method of the recoilcurve decomposition into the constituent magnetization components was described elsewhere. ${ }^{10,11}$ The samples used for the magnetic measurements were in the form of ribbons of known dimensions. The demagnetization field resulting from their shape was taken into account and evaluated with the method described in ${ }^{12}$.

\subsection{Hysteresis model}

In the original $T(x)$ model, ${ }^{13,14}$ the hysteresis loop can be described with the sum of sigmoid and linear functions. The sigmoid hysteretic function characterizes the irreversible magnetization changes. The linear one is used for describing the reversible magnetization changes. In this research the authors used the $T(x)$ model modified by Dośpial, ${ }^{15,16}$ describing the reversible magnetization component with an anhysteretic sigmoid function. Based on this assumption, the whole reversal magnetization process was described with following Equations:

$f_{r,+}^{\text {hys }}=\mu_{0} M_{\mathrm{R}} \sum_{i=1}^{n_{\text {irt }}} B_{0,1}\left(\tanh \left[C_{0, i}\left(x-a_{0, i}\right)\right]+b_{+, i}-b_{1, i}\right)(1 \mathrm{a})$

$f_{r,+}^{\text {anhys }}=\mu_{0} M_{\text {rev }}^{\max }$.

$\cdot\left(\sum_{j=1}^{n_{\text {rev }}} B_{0, j} \frac{\tanh \left[C_{0, j}\left(x+a_{0, j}\right)\right]+\tanh \left[C_{0, j}\left(x-a_{0, j}\right)\right]}{2}\right)^{(1 \mathrm{~b})}$

$b_{+, i}=\tanh \left[C_{0, i}\left(x_{k}+a_{0, i}\right)\right]-\tanh \left[C_{0, i}\left(x_{k}-a_{0, i}\right)\right]$

$f_{r,-}^{\text {hys }}=\mu_{0} M_{\mathrm{R}} \sum_{i=1}^{n_{\text {irr }}} B_{0,1}\left(\tanh \left[C_{0, i}\left(x+a_{0, i}\right)\right]+b_{-, i}+b_{1, i}\right)$

$f_{r,-}^{\text {anhys }}=\mu_{0} M_{\text {rev }}^{\max }$.

$\left(\sum_{j=1}^{n_{\mathrm{rev}}} B_{0, j} \frac{\tanh \left[C_{0, j}\left(x+a_{0, j}\right)\right]+\tanh \left[C_{0, j}\left(x-a_{0, j}\right)\right]}{2}\right)$

$b_{-, i}=\tanh \left[C_{0, i}\left(x_{k}-a_{0, i}\right)\right]-\tanh \left[C_{0, i}\left(x_{k}+a_{0, i}\right)\right]$

$b_{1, i}=\frac{\tanh \left[C_{0, i}\left(x_{m}+a_{0, i}\right)\right]-\tanh \left[C_{0, i}\left(x_{m}-a_{0, i}\right)\right]}{2}$

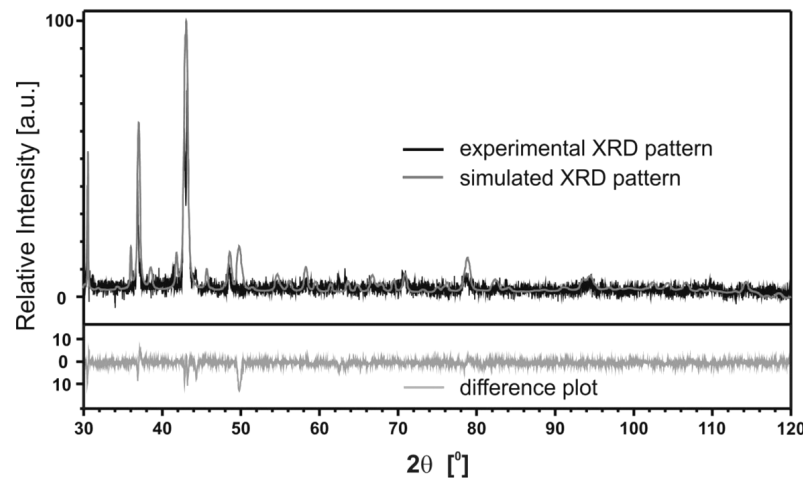

Figure 1: X-ray diffraction patterns: measured and calculated from the Rietveld refinement and the difference curve for a $\mathrm{Sm}_{12.5} \mathrm{Fe}_{8} \mathrm{Co}_{66.5} \mathrm{Si}_{2} \mathrm{Cu}_{11}$ ribbon annealed at $850{ }^{\circ} \mathrm{C}$ for $3 \mathrm{~h}$

Slika 1: Rentgenogram, izmerjen in izračunan iz Rietveld-ovega približka, ter diferenčna krivulja za trak $\mathrm{Sm}_{12,5} \mathrm{Fe}_{8} \mathrm{Co}_{66,5} \mathrm{Si}_{2} \mathrm{Cu}_{11}$, žarjen 3 h na $850{ }^{\circ} \mathrm{C}$

where $\left(_{+}\right)$and $\left(_{-}\right)$in the $f_{ \pm}^{\text {hys, anhys }}$ functions represent the ascending and descending changes of the reversible (anhys) and irreversible (hys) components, respectively; $x$ is the external-magnetic-field excitation, $a_{0 i}$ is the center of the $i^{\text {th }}$ pinning/nucleation site, $a_{0 i}$ is the center of the $j^{\text {th }}$ reversible process; $B_{0, i}, B_{0, j}$ are the amplitudes of the $i^{\text {th }}$ and $j^{\text {th }}$ magnetization components; $C_{0, i}, C_{0, j}$ are the sheering factors, while $x_{\mathrm{m}}$ represents the maximumexternal-magnetic-field excitation. The $i$ and $j$ indexes refer to individual reversible and irreversible magnetization components, respectively, and $n_{\text {irr,rev }}$ is their total number. ${ }^{16}$

\section{RESULTS AND DISCUSSION}

Figure 1 presents the experimental X-ray diffraction pattern compared with the results of the Rietveld refinement simulation, obtained for the annealed $\mathrm{Sm}_{12.5} \mathrm{Fe}_{8} \mathrm{Co}_{66.5} \mathrm{Si}_{2} \mathrm{Cu}_{11}$ thin ribbons.

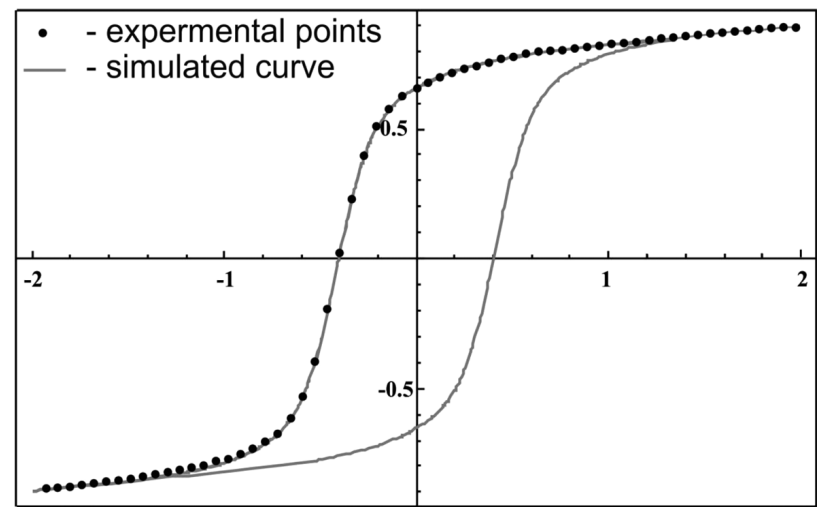

Figure 2: Measured demagnetization curve and the calculated hysteresis loop, obtained with the modified $T(x)$ model, for the $\mathrm{Sm}_{12.5} \mathrm{Fe}_{8} \mathrm{Co}_{66.5} \mathrm{Si}_{2} \mathrm{Cu}_{11}$ ribbon annealed at $850{ }^{\circ} \mathrm{C}$ for $3 \mathrm{~h}$

Slika 2: Izmerjena krivulja razmagnetenja, izračunana $\mathrm{z}$ modificiranim modelom $T(x)$ histerezne zanke za trak $\mathrm{Sm}_{12,5} \mathrm{Fe}_{8} \mathrm{Co}_{66,5} \mathrm{Si}_{2} \mathrm{Cu}_{11}$, žarjen 3 h na $850^{\circ} \mathrm{C}$ 
According to the Rietveld refinement, it was found that the studied alloy was composed from $\mathrm{Sm}_{2} \mathrm{Co}_{17}$ (22.92\%), $\mathrm{SmCo}_{7}(37.45 \%)$ and $\mathrm{SmCo}_{5}(39.63 \%)$ phases. A lack of one of the less intense peaks on the experimental diffraction pattern, as compared with the simulation, can be associated with the preferred position, occupied by the $\mathrm{Cu}$ atoms in the $\mathrm{TbCu}_{7}$ structure and the use of a copper X-ray source. Due to the overlapping peaks, originating from the presence of different crystalline phases, it was not possible to estimate the average grain size using the Bragg equation. However, it was possible to state that it was less than about $120 \mathrm{~nm}$.

With the measured demagnetization curve and the simulated one, obtained with the modified hyperbolic $T(x)$ model, the major hysteresis loop is presented in Figure 2.

The experimentally determined hysteresis loop was used to estimate the basic magnetization parameters: saturation of the magnetization $\mu_{0} M_{\mathrm{S}}(0.90 \mathrm{~T})$, remanence $\mu_{0} M_{\mathrm{R}}(0.70 \mathrm{~T})$ and coercivity ${ }_{\mathrm{J}} H_{\mathrm{C}}(0.41 \mathrm{~T})$.

The saturation of the magnetization and the remanence were also compared with those calculated from the initial magnetization curve and the irreversible magnetization dependence after the extrapolation to the infinite field, using the method described elsewhere. ${ }^{17}$ The calculated parameters were as follows: $\mu_{0} M_{\mathrm{S}}(\infty)=0.91 \mathrm{~T}$ and $\mu_{0} M_{\mathrm{R}}(\infty)=0.70 \mathrm{~T}$; they were used to obtain the $M_{\mathrm{r}}(\infty) / M_{\mathrm{s}}(\infty)$ ratio which was 0.77 .

On the basis of the $M_{\mathrm{r}}(\infty) / M_{\mathrm{s}}(\infty)$ ratio combined with the shape of the demagnetization curve and the estimated grain size, it was possible to conclude which type of interactions between the particles is dominant. According to the literature, ${ }^{18,19}$ a multiphase material with a smooth demagnetization curve (as observed on Figure 2) and the value of the $M_{\mathrm{R}} / M_{\mathrm{S}}$ ratio higher than 0.5 is characteristic for exchange-coupled nanocomposites and/or anisotropic permanent magnets.

The measured demagnetization curve (the lower arm of the hysteresis is symmetric) was compared with the

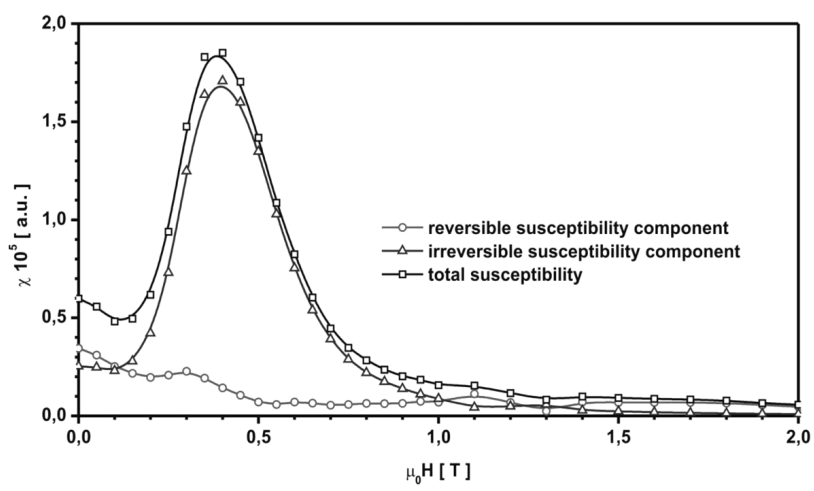

Figure 3: Reversible, irreversible and total susceptibilities determined from the magnetization components for a $\mathrm{Sm}_{12.5} \mathrm{Fe}_{8} \mathrm{Co}_{66.5} \mathrm{Si}_{2} \mathrm{Cu}_{11}$ ribbon annealed at $850{ }^{\circ} \mathrm{C}$ for $3 \mathrm{~h}$

Slika 3: Reverzibilna, ireverzibilna in skupna občutljivost, določena iz komponent magnetizacije za trak $\mathrm{Sm}_{12,5} \mathrm{Fe}_{8} \mathrm{Co}_{66,5} \mathrm{Si}_{2} \mathrm{Cu}_{11}$, žarjen $3 \mathrm{~h}$ na $850{ }^{\circ} \mathrm{C}$ theoretically simulated hysteresis loop (Figure 2). The simulation was done using the Mathematica software and Equations (1) to (3). The obtained results showed a high compliance with the experiment.

The startup data for simulating the major hysteresis loop and recoil curve was determined on the basis of the data obtained from the analysis of the reversible and irreversible magnetic susceptibilities (Figure 3).

As it can be seen on Figure 3, both reversible and irreversible susceptibilities are composed of at least three distribution sites. The fitting parameters determined from susceptibility curves are gathered in Table 1.

In order to simulate the irreversible magnetization changes, it was necessary to use a combination of three hysteretic functions, properly representing three pinning/ nucleation sites. On the other hand, the reversible magnetization was represented by a combination of three anhysteretic functions, sourcing from the rotation of magnetization vectors, the free domain-wall movement of unpinned domain walls or the bowing of strongly pinned domain walls.

Table 1: Fitting parameters used in the simulation of the major hysteresis loop and recoil curve applying the modified $T(x)$ model, where: $a_{0 i}$ - the center of the $i^{\text {th }}$ pinning/nucleation site (irreversible) or the peak resulting from the reversible process, $B_{0 i}$ - the amplitude of the $i^{\text {th }}$ magnetization component, $C_{0 i}$ - the shearing factor of the $i^{\text {th }}$ magnetization component

Tabela 1: Parametri ujemanja, uporabljeni pri simulaciji glavne histerezne zanke in povratne krivulje $\mathrm{z}$ uporabo modificiranega modela $T(x)$, kjer je: $a_{0 i}-$ sredina $i^{\text {th }}$ nukleacije (ireverzibilno) ali vrh pri reverzibilnem procesu, $B_{0 i}$ - amplituda $i^{\text {th }}$ magnetizacijske komponente, $C_{0 i}-$ strižni faktor $i^{\text {th }}$ magnetizacijske komponente

\begin{tabular}{|c|c|c|c|c|}
\hline \multicolumn{2}{|c|}{ Component } & $\boldsymbol{C}_{\mathbf{0} \boldsymbol{i}}$ & $\boldsymbol{a}_{\mathbf{0 i}}$ & $\boldsymbol{B}_{\mathbf{0}}$ \\
\hline \multirow{3}{*}{$\operatorname{rev}$} & 1 & 2.705 & 0.001 & 0.079 \\
\cline { 2 - 5 } & 2 & 0.107 & 0.320 & 0.354 \\
\cline { 2 - 5 } & 3 & 0.114 & 1.200 & 0.204 \\
\hline \multirow{3}{*}{$\operatorname{irr}$} & 1 & 0.039 & 0.022 & 0.355 \\
\cline { 2 - 5 } & 2 & 5.618 & 0.413 & 0.589 \\
\cline { 2 - 5 } & 3 & 2.672 & 0.749 & 0.081 \\
\hline
\end{tabular}

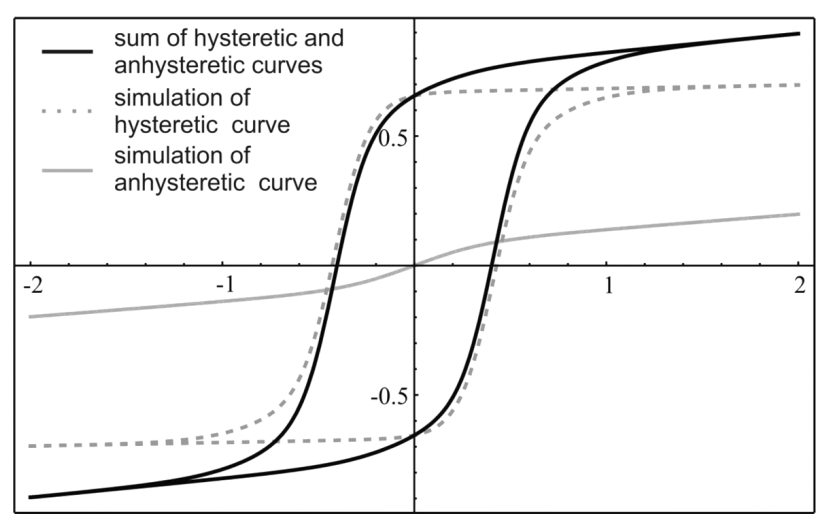

Figure 4: Decomposition of the hysteresis loop simulated with the modified $T(x)$ model into the hysteretic and anhysteretic functions

Slika 4: Razstavljanje $\mathrm{z}$ modificiranim modelom $T(x)$ simulirane histerezne zanke $\mathrm{v}$ histerezno in antihisterezno funkcijo 


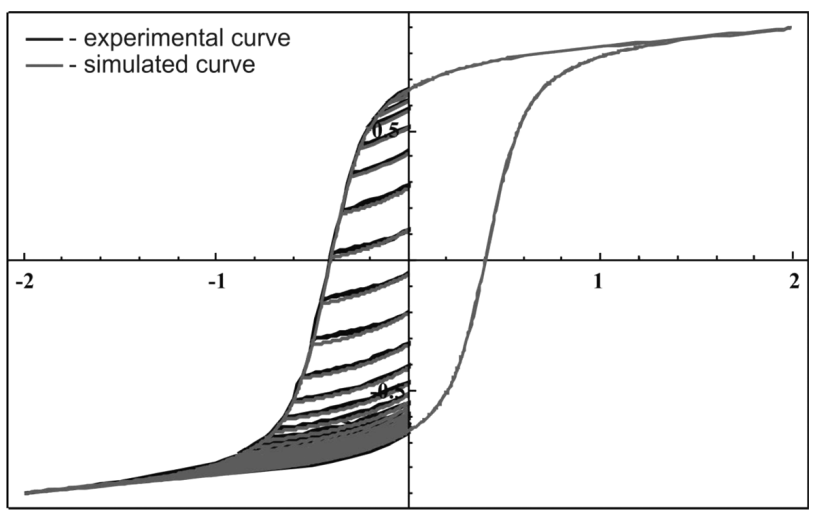

Figure 5: Comparison of the measured and simulated, with the modified $T(x)$ model, recoil loops for the $\mathrm{Sm}_{12.5} \mathrm{Fe}_{8} \mathrm{Co}_{66.5} \mathrm{Si}_{2} \mathrm{Cu}_{11}$ ribbon annealed at $850{ }^{\circ} \mathrm{C}$ for $3 \mathrm{~h}$

Slika 5: Primerjava izmerjenih in $\mathrm{z}$ modificiranim modelom $T(x)$ simuliranih povratnih krivulj za trak $\mathrm{Sm}_{12,5} \mathrm{Fe}_{8} \mathrm{Co}_{66,5} \mathrm{Si}_{2} \mathrm{Cu}_{11}$, žarjen 3 h na $850{ }^{\circ} \mathrm{C}$

The decomposition of the hysteresis loop into the hysteretic and anhysteretic curves, representing irreversible and reversible magnetization processes, respectively, is presented in Figure 4.

The obtained results were also used for simulating the recoil curve in the demagnetization direction by applying Equations (1) to (3). The comparison of the simulated and measured recoil loops is presented in Figure 5.

As can be seen in Figure 5, the simulated and measured curves are similar. The observed small differences between the experiment and the simulation can be related to the recoil-loop openness effect that is, in turn, associated with the magnetic viscosity.

\section{CONCLUSION}

From the X-ray diffraction it was found that the studied sample was composed of three different phases, i.e., $\mathrm{Sm}_{2} \mathrm{Co}_{17}(22.92 \%), \mathrm{SmCo}_{7}(37.45 \%)$ and $\mathrm{SmCo}_{5}$.

The analysis of the parameters determined from the hysteresis loop and its shape revealed that the $M_{\mathrm{r}} / M_{\mathrm{s}}$ ratio was higher than $0.5(0.77)$. Such an increase in the value of the aforementioned ratio is typically met in the samples characterized by a high anisotropy ${ }^{20}$ or strong exchange coupling between nanosized grains. ${ }^{18,19}$ The multiphase composition combined with a smooth, single-step demagnetization curve can be treated as a proof of strong exchange coupling between the grains of the constituent phases. ${ }^{21}$

The decomposition of the demagnetization curve into the reversible and irreversible magnetization components provided information on the quantity and type of the reversal-magnetization processes occurring in the studied material. Furthermore, using the obtained results and the $T(x)$ model modified by Dospial, it was possible to determine the anhysteretic and hysteretic curves forming the hysteresis. The same data was used to simulate the recoil curve that showed a high compliance with the experimentally obtained one.

\section{Acknowledgement}

This work was supported by the Ministry of Science and Higher Education of Poland through Grant No. N N507 234940.

\section{REFERENCES}

${ }^{1}$ L. Peng, H. Zhang, J. Q. Xiao, Enhanced coercivity of melt-spun $\mathrm{Sm}(\mathrm{Co}, \mathrm{Fe}, \mathrm{Cu}, \mathrm{Zr})_{\mathrm{z}}$ ribbons annealed by improved process, Journal of Magnetism and Magnetic Materials, 320 (2008), 1377-1381, doi:10.1016/j.jmmm.2007.11.012

${ }^{2}$ M. Dospial, M. Nabialek, M. Szota, D. Plusa, The magnetization reversal processes of $\mathrm{Sm}_{2} \mathrm{Gd}_{10.5} \mathrm{Fe}_{8} \mathrm{Co}_{64} \mathrm{Zr}_{2.5} \mathrm{Cu}_{13}$ alloy in the as-quenched state, Journal of Alloys and Compounds, 509 (2011), S404-S407, doi:10.1016/j.jallcom.2010.12.043

${ }^{3}$ H. Tang, Y. Liu, D. J. Sellmyer, Nanocrystalline $\operatorname{Sm}_{12.5}(\mathrm{Co}, \mathrm{Zr})_{87.5}$ magnets: synthesis and magnetic properties, Journal of Magnetism and Magnetic Materials, 241 (2002) 2-3, 345-356, doi:10.1016/ S0304-8853(01)00978-7

${ }^{4}$ C. Jiang, M. Venkatesan, K. Gallagher, J. M. D. Cody, Magnetic and structural properties of $\mathrm{SmCo}_{7-\mathrm{x}} \mathrm{Ti}_{\mathrm{x}}$ magnets, Journal of Magnetism and Magnetic Materials, 236 (2001) 1, 49-55, doi:10.1016/ S0304-8853(01)00451-6

${ }^{5}$ J. Zhou, I. A. Al-Omari, J. P. Liu, D. I. Sellmyer, Structure and magnetic properties of $\mathrm{SmCo}_{7-\mathrm{x}} \mathrm{Ti}_{\mathrm{x}}$ with $\mathrm{TbCu}_{7}$-type structure, Journal of Applied Physics, 87 (2000), 5299, doi:10.1063/1.373327

${ }^{6}$ M. J. Dospial, M. G. Nabialek, M. Szota, T. Mydlarz, K. Ozga, S. Lesz, Influence of heat treatment on structure and reversal magnetization processes of $\mathrm{Sm}_{12.5} \mathrm{Co}_{66.5} \mathrm{Fe}_{8} \mathrm{Cu}_{13}$ alloy, Journal of Alloys and Compounds, 536 (2012), S324-S328, doi:10.1016/j.jallcom.2011. 11.096

${ }^{7}$ Y. Q. Guo, W. Li, J. Luo, W. C. Feng, J. K. Liang, Structure and magnetic characteristics of novel SmCo-based hard magnetic alloys, Journal of Magnetism and Magnetic Materials, 303 (2006), e367-e370, doi:10.1016/j.jmmm.2006.01.036

${ }^{8}$ Y. Guo, W. Li, W. Feng, J. Luo, J. Liang, Q. He, X. Yu, Structural stability and magnetic properties of $\mathrm{SmCo}_{7-\mathrm{x}} \mathrm{Ga}_{\mathrm{x}}$, Applied Physics Letters, 86 (2005), 192513, doi:10.1063/1.1926416

${ }^{9}$ J. Birkenstock, R. X. Fischer, T. Messner, BRASS 1.0 beta: The Bremen Rietveld Analysis and Structure Suite, Zentrallabor für Kristallographie und Angewandte Materialwissenschaften, Fachbereich Geowissenschaften, University of Bremen, 2003

${ }^{10}$ D. C. Crew, P. G. McCormick, R. Street, An investigation of reversible magnetization in $\mathrm{NdFeB}$, Journal of Applied Physics, 86 (1999), 3278, doi:10.1063/1.371202

${ }^{11}$ M. Dospial, D. Plusa, Magnetization reversal processes in bonded magnets made from a mixture of $\mathrm{Nd}-(\mathrm{Fe}, \mathrm{Co})-\mathrm{B}$ and strontium ferrite powder, Journal of Magnetism and Magnetic Materials, 330 (2013), 152-158, doi:10.1016/j.jmmm.2012.10.022

${ }^{12}$ A. K. Panda, S. Basu, A. Mitra, Demagnetization effect and its correction on the measurement of magnetic hysteresis loop of melt-spun ribbons, Journal of Magnetism and Magnetic Materials, 261 (2003), 190-195, doi:10.1016/S0304-8853(02)01472-5

${ }^{13}$ J. Takacs, Mathematics of Hysteresis Phenomena, Wiley-VCH Verlag, Weinheim 2003

${ }^{14}$ J. Takacs, I. Mészŕros, Separation of magnetic phases in alloys, Physica B, 403 (2008), 3137-3140, doi:10.1016/j.physb.2008.03.023

${ }^{15}$ M. Dospial, M. Nabialek, M. Szota, P. Pietrusiewicz, K. Gruszka, K. Bloch, Modeling the hysteresis loop in hard magnetic materials using $\mathrm{T}(\mathrm{x})$ model, Acta Physica Polonica A, 126 (2014), 170-171, doi:10.12693/APhysPolA.126.170 
${ }^{16}$ M. Dospial, Modeling the hysteresis loop of the nanocomposite material using modified hyperbolic $\mathrm{T}(\mathrm{x})$ model, Acta Physica Polonica A, 127 (2015), 415-417, doi:10.12693/APhysPolA.127.415

${ }^{17}$ H. Zijlstra, Experimental methods in magnetism, Elsevier NorthHolland, Amsterdam 1967

${ }^{18}$ H. Kronmüller, D. Goll, Micromagnetic analysis of nucleationhardened nanocrystalline PrFeB magnets, Scripta Materialia, 47 (2002) 8, 551-556, doi:10.1016/S1359-6462(02)00176-8

${ }^{19}$ E. F. Kneller, R. Hawig, The exchange-spring magnet: a new material principle for permanent magnets, Magnetics, IEEE Transactions, 27 (1991) 4, 3588-3560, doi:10.1109/20.102931
${ }^{20}$ G. Ruwei, Z. Shouzeng, Z. Deheng et al., Coercivity and its dependence on the strength of alignment magnetic field in $\mathrm{Nd}-\mathrm{Fe}-\mathrm{B}$ sintered magnets, Journal of Applied Physics, 78 (1995) 2, 1156, doi:10.1063/1.360350

${ }^{21}$ A. E. Ceglarek, D. Plusa, M. J. Dospial, M. G. Nabialek, P. Pietrusiewicz, Investigation of the Magnetization Reversal Process of High-Remanent $\mathrm{Nd}_{10} \mathrm{Fe}_{83} \mathrm{Zr}_{1} \mathrm{~B}_{6}$ Alloy in the As-Cast State, Acta Physica Polonica A, 121 (2012) 5-6, 1279-1281 